\title{
PERBEDAAN KAJIAN ANTROPOLOGI HUKUM DENGAN ILMU SOSIAL LAINNYA
}

\author{
Alzikra Maulana Adfin \\ Email: alzikraadfin12@gmail.com \\ No BP: 2110003600176 \\ Universitas Ekasakti Padang
}

\section{A. PENDAhuluan}

Istilah antropologi berasal dari bahasa yunani, asal kata anthropos berarti manusia, dan logos berarti ilmu. Dengan demikian, secara harfiah antropologi ilmu tentang manusia. Pendekatan yang digunakan dalam antropologi menggunakan pendekatan kuantitatif (positivistik) dan kualitatif (naturalistic). Antropologi adalah ilmu tentang umat manusia yang berusaha menyusun generalisasi yang bermanfaat tentang manusia dan perilakunya, dan untuk memperoleh pengertian ataupun pemahaman yang lengkap tentang keanekaragaman manusia (Haviland, 1999; Koentjaraningrat, 1987).

Tujuan dari ilmu antropologi untuk memperluas arena perbandingan di samping untuk merekam budaya sebelum budaya budaya itu lenyap dan mencari suatu bangsa atau kelompok yang belum pernah di teliti. Ilmu antropologi erat kaitannya dengan ilmu sosial lainnya seperti sosiologi, geografi, sejarah, ilmu politik, psikologi dan ilmu-ilmu sosial lainnya. Antropologi mulai berkembang pada abad ke-15 dan terus berkembang hingga sekarang.Dalam ilmu antropologi hukum dipelajari juga mengenai Peran, Status atau kedudukan, Nilai, Norma dan juga Budaya atau kebudayaan. Ke semuanya ini merupakan hal-hal yang sangat erat kaitannya dengan ilmu antropologi hukum. 
Antropologi hukum adalah salah satu ilmu yang saat ini masih dalam tahap pertumbuhan. Ini mempelajari kekhasan bentuk hukum aktivitas manusia dalam periode sejarah yang berbeda dan dalam keadaan yang sama sekali berbeda. Antropologi hukum adalah kajian antropologis terhadap makna sosial dari dan pentingnya hukum dengan menelaah bagaimana hukum dibuat termasuk bagaimana konteks sosial pembuatan hukum tersebut, bagaimana hukum mempertahankan dan mengubah institusi sosial lainnya, dan bagaimana hukum membangun

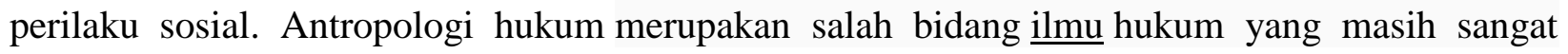
jarang diketahui oleh masyarakat luas. Orang lebih mengenal antropologi sebagai bidang ilmu yang dekat dengan peristiwa sejarah dan budaya dan karena itu tidak mungkin memiliki kaitan dengan ilmu hukum. Namun inilah hukum, bidang ilmu yang sangat luas dan mencakup hampir seluruh aspek kehidupan manusia.

Awal 1970-an dapat dicatat sebagai formulasi dari perkembangan pendidikan ilmu hukum empiris dengan menggunakan pendekatan sosiologis untuk mengkaji fenomenafenomena hukum dalam masyarakat sedang berkembang di Indonesia, yang dikenal kemudian sebagai disiplin sosiologi hukum (sociology of law). Nama-nama akademisi hukum seperti Soerjono Soekanto (alm.) dari UI, Satjipto Rahardjo dari UNDIP, dan Sutandyo Wignyosubroto dari UNAIR dapat dicatat sebagai para perintis pengenalan mata kuliah sosiologi hukum di fakultasfakultas hukum di Jawa.

Kemudian, sejak warsa 1980-an dunia pendidikan ilmu hukum di Indonesia semakin diperkaya dengan pengenalan studi-studi hukum empiris dengan menggunakan pendekatan antropologis. Untuk ini, T.O. Ihromi dan Valerine J.L. Kriekhoff dari UI bekerjasama dengan F. von BendaBeckmann dari Wageningen Agriculture University the Netherlands dapat dinobatkan sebagai 
peletak dasar studi-studi antropologis tentang hukum yang kemudian dikenal sebagai antropologi hukum (anthropology of law,legal anthropology, anthropological study of law).

Antropologi hukum pada dasarnya mempelajari hubungan timbalbalik antara hukum dengan fenomena-fenomena sosial secara empiris dalam kehidupan masyarakat; bagaimana hukum berfungsi dalam kehidupan masyarakat, atau bagaimana hukum bekerja sebagai alat pengendalian sosial (social control) atau sarana untuk menjaga keteraturan sosial (social order) dalam masyarakat. Dengan kata lain, studi-studi antropologis mengenai hukum memberi perhatian pada segi-segi kebudayaan manusia yang berkaitan dengan fenomena hukum dalam fungsinya sebagai sarana menjaga keteraturan sosial atau alat pengendalian sosial. Karena itu, studi antropologis mengenai hukum secara khusus mempelajari prosesproses sosial di mana pengaturan mengenai hak dan kewajiban warga masyarakat diciptakan, dirobah, dimanipulasi, diinterpretasi, dan diimplementasikan oleh warga masyarakat (F. von BendaBeckmann, 1979, 1986). 


\section{B. PEMBAHASAN}

Antropologi hukum merupakan cabang ilmu pengetahuan hukum yang mempelajari pola-pola sengketa dan penyelesaiannya, baik pada masyarakat yang sederhana maupun pada masyarakat

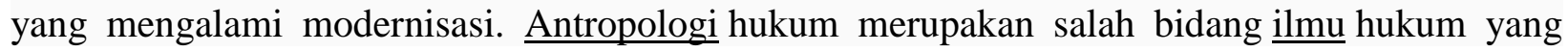
masih sangat jarang diketahui oleh masyarakat luas. Orang lebih mengenal antropologi sebagai bidang ilmu yang dekat dengan peristiwa sejarah dan budaya dan karena itu tidak mungkin memiliki kaitan dengan ilmu hukum. Namun inilah hukum, bidang ilmu yang sangat luas dan mencakup hampir seluruh aspek kehidupan manusia.

Berikut perbedaan kajian antropologi hukum dengan ilmu sosial lainnya :

1. Perbedaan kajian antropologi hukum dengan sosiologi

Sosiologi dan antropologi hukum memiliki kemiripan yang sangat tinggi jika diamati secara sepintas. Keduanya memiliki objek kajian yang sama yaitu masyarakat, akan tetapi antropologi hukum ini berkaitan dengan hukum yang ada. Namun, demikian kedua disiplin ilmu ini dapat dibedakan dari asal-usul, pendekatan kajian, metode kajiannya. Antropologi hukum pada dasarnya mempelajari hubungan timbalbalik antara hukum dengan fenomena-fenomena sosial secara empiris dalam kehidupan masyarakat; bagaimana hukum berfungsi dalam kehidupan masyarakat, atau bagaimana hukum bekerja sebagai alat pengendalian sosial (social control) atau sarana untuk menjaga keteraturan sosial (social order) dalam masyarakat. Dengan kata lain, studi-studi antropologis mengenai hukum memberi perhatian pada segi-segi kebudayaan manusia yang berkaitan dengan fenomena hukum dalam fungsinya sebagai sarana menjaga keteraturan sosial atau alat pengendalian sosial 
Sosiologi adalah pengetahuan atau ilmu tentang sifat masyarakat, perilaku masyarakat, dan perkembagan masyarakat. Sosiologi merupakan cabang ilmu sosial yang mempelajari masyarakat dan pengaruhnya terhadap kehidupan manusia antropologi mirip seperti sosiologi tetapi pada sosiologi lebih menitik beratkan pada masyarakat dan kehidupan sosialnya (Koentjaraningrat,1992).

2. Perbedaan kajian antropologi hukum dengan sejarah

Antropologi memberi bahan prehistori sebagai pangkal bagi tiap penulis sejarah dari tiap bangsa di dunia. Kecuali itu, banyak masalah dalam historigrafi dari sejarah sesuatu bangsa dapat dipecahkan dengan metode-metode antropologi. Banyak sumber sejarah berupa prasasti, dokumen, naskah tradisional, dan arsip kuno, sering hanya dapat memberi peristiwa-peristiwa sejarah yang terbatas kepada bidang politik saja. Sebaliknya, seluruh latar belakang sosial dari peristiwa-peristiwa politik tadi sukar diketahui hanya dari sumber-sumber tadi. Konsep-konsep tentang kehidupan masyarakat yang dikembangkan oleh antropologi dan ilmu-ilmu sosial lainnya, akan memberi pengertian banyak kepada seorang ahli sejarah untuk mengisi latar belakang dari peristiwa politik dalam sejarah yang menjadi obyek penelitiaannya.

Para ahli antroopologi sebaliknya juga memerlukan sejarah terutama sejarah dari sukusuku bangsa dalam daerah yang di datanginya. Sejarah itu diperlukan olehnya untuk memecahkan soal-soal yang terjadi karena masyarakat yang di telitinya mengalami pengaruh dari suatu kebudayaan dari luar. Pengertian terhadap soal-soal tadi baru dapat dicapainya apabila sejarah tentang proses pengaruh tadi diketahuinya juga dengan teliti. Kecuali mengetahui tantang sejarah dari suatu proses perpaduan kebudayaan, seringkali 
terjadi bahwa sejarah tadi masih harus direkonstruksi sendiri oleh seorang peneliti. Dengan demikian seorang sarjana antropologi seringkali harus juga memiliki pengeahuan tentang metode-metode untuk merekonstrusi sejarah dari suatu rangkaian peristiwa.

3. Perbedaan kajian antropologi hukum dengan arkeologi

Antropologi mempunyai sebagian tugas, meneliti sejarah kebudayaan manusia yang lebih kuno dari zaman kejayaan kebudayaan-kebudayaan tersebut, yaitu zaman sebelum manusia mengenal huruf, atau zaman prehistori. Penelitian-penelitian itu dilakukan oleh sub-ilmu dari antropologi yang bernama prehistori, dengan menggunakan sebagai bahan penelitian sisa-sisa benda kebudayaan manusia yang tertinggal dalam lapisan-lapisan bumi. Dengan demikian sub-ilmu prehistori dari ilmu antropologi dari ilmu antropologi dapat dikatakan memperpanjang jarak waktu dari sejarah kebudayaan manusia dengan bahan-bahan yang lebih tua dari piramida-piramida, candi-candi, dan buku-buku kuno. Dan demikian pula ilmu arkeologi Indonesia dapat kembali hinga zaman candi-candi atau prasasti-prasasti yang tertua (yaitu abad ke-4), sedangkan ilmu prehistori dapat kembli himgga berpuluh ribu tahun sebelum itu, ke zaman-zaman yang disebut zaman Neolithik, zaman Paleolithik dan sebagainnya.

Lepas dari menambanh bahan dari zaman yang jauh lebih tua, ilmu antropoloogi dapat juga memberi keterangan tentang bagian dari kebudayaan sesuatu bangsa yang tidak dapat diberikan oleh ilmu-ilmu lain yang meneliti kebudayaan, seperti ilmu arkeologi Indonesia misalnya, meneliti kebudayaan-kebudayaan kuno dari lapisan sosial kecil saja, yaitu lapisan sosial di istana raja-raja yang membangun candi-candi, dan menulis prasasti-prasasti serta buku-buku kuno . Sebaliknya ilmu antropologi Indonesia dapat 
menambah pengetahuan kita tentang kebudayaan Indonesia pada umumnya dengan memberikan kepada kita bahan tentang kebudayaan raktyat jelata yang tingga di desadesa.

Arkeologi (atau ilmu sejarah kebudayaan purbakala) pada mulanya meneliti sejarah dari kebudayaan-kebudayaan kuno dalam zaman purba, seperti kebudayaan Yunani dan Rum Klasik, kebudayaan Mesir Kuno didaerah Mesopotamia, kebudayaan kuno di Palestiandan sebagainya. Di Indonesia ilmu arkeologi antara lain meneliti sejarah dari Negara-negara Indonesia-Hindu diantara abad ke-4 sampai abad ke-16 masehi.

Penelitian kebudayaan-kebudayaan kuno tadi mempergunakan sebagai bahan penelitian, bekas-bekas bangunan kuno, (runtuhan-runtuhan kuil istana, bangunan irigasi, piramida candi dan sebagainnya), tetapi juga prasasti-prasati atau buku-buku kuno yang ditulis dalam zaman kebudayaan-kebudayaan itu memuncak.

4. Perbedaan kajian antropologi hukum dengan psikologi Antropologi hukum pada dasarnya mempelajari hubungan timbalbalik antara hukum dengan fenomena-fenomena sosial secara empiris dalam kehidupan masyarakat; bagaimana hukum berfungsi dalam kehidupan masyarakat, atau bagaimana hukum bekerja sebagai alat pengendalian sosial (social control) atau sarana untuk menjaga keteraturan sosial (social order) dalam masyarakat. Dengan kata lain, studi-studi antropologis mengenai hukum memberi perhatian pada segi-segi kebudayaan manusia yang berkaitan dengan fenomena hukum dalam fungsinya sebagai sarana menjaga keteraturan sosial atau alat pengendalian sosial. 
Antropologi psikologi merupakan bagian dari ilmu antropologi, yang terutama berkembang di Amerika dan yang kini sudah menjadi sedemikian luasnya, sehingga dapat dikatakan merupakan sub ilmu tersendiri. Pengetahuan para ahli antropologi psikologi dalam ilmu, teori-teori, dan metodologi psikologipun harus cukup mendalam. Antropologi psikologi mula-mula berkembang karena: (1)ada ahli-ahli antropologi yang dalam usaha memandang suatu kebudayaan sebagai suatu kesatuan yang holistic, memfokus pada "watak khas" atau ethos, yang dipancarkan oleh kebudayaan yang sedang diteliti, (2) karena ada yang berhasrat meneliti sampai dimana konsep-konsep atau teori-teori psikologi yang dikembangkan berdasarkan data dari kebudayaan-kebudayaan Eropa Barat dan Amerika metropolitan, bersifat universal dan dapat diterapkan pada individu-individu yang hidup dalam kebudayaan dan masyarakat diluar lingkungan itu, (3)juga karena ada yang berkeinginan mendeskripsi kepribadian umum penduduk dari suatu kebudayaan tertentu dengan cara yang lebih ilmiah dan lebih teliti. 


\section{PENUTUP}

Antropologi hukum pada dasarnya mempelajari hubungan timbalbalik antara hukum dengan fenomena-fenomena sosial secara empiris dalam kehidupan masyarakat; bagaimana hukum berfungsi dalam kehidupan masyarakat, atau bagaimana hukum bekerja sebagai alat pengendalian sosial (social control) atau sarana untuk menjaga keteraturan sosial (social order)

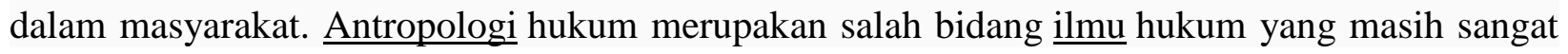
jarang diketahui oleh masyarakat luas. Orang lebih mengenal antropologi sebagai bidang ilmu yang dekat dengan peristiwa sejarah dan budaya dan karena itu tidak mungkin memiliki kaitan dengan ilmu hukum. Namun inilah hukum, bidang ilmu yang sangat luas dan mencakup hampir seluruh aspek kehidupan manusia.

Perbedaan kajian antropologi hukum dengan ilmu sosial lainnya seperti sosiologi,sejarah, arkeologi dan psikologi sangatlah jelas. Namun ilmu-ilmu ini tetap membahas tentang kehidupan manusia atau masyarakat, akan tetapi antropologi hukum lebih dekat dengan keadaan dan kajian bidang hukum yang ada disekitar manusia. Berbeda dengan ilmu sosial lain yang pembahasan atau kajianya tidak berkaitan dengan hukum. 


\section{DAFTAR PUSTAKA}

Darmini Roza dan Laurensius Arliman S, Peran Pemerintah Daerah Di Dalam Melindungi Hak Anak Di Indonesia, Masalah-Masalah Hukum, Volume 47, Nomor 1, 2018. https://doi.org/10.14710/mmh.47.1.2018.10-21

Laurensius Arliman S, Peranan Metodologi Penelitian Hukum di Dalam Perkembangan Ilmu Hukum di Indonesia, Soumatera Law Review, Volume 1, Nomor 1, 201. http://doi.org/10.22216/soumlaw.v1i1.3346.

Laurensius Arliman S, Peran Badan Permusyawaratan Desa di Dalam Pembangunan Desa dan Pengawasan Keuangan Desa, Padjadjaran Journal of Law, Volume 4, Nomor 3, 2017. https://doi.org/10.15408/jch.v4i2.3433.

Laurensius Arliman S, Penanaman Modal Asing Di Sumatera Barat Berdasarkan Undang- Undang Nomor 25 Tahun 2007 Tentang Penanaman Modal, Supremasi Hukum, Volume 1, Nomor 1, 2018. http://dx.doi.org/10.36441/hukum.v1i01.102 .

Laurensius Arliman S, Memperkuat Kearifan Lokal Untuk Menangkal Intoleransi Umat Beragama Di Indonesia, Ensiklopedia of Journal, Volume 1, Nomor 1, 2018, https://doi.org/10.33559/eoj.v1i1.18.

Laurensius Arliman S, Perkawinan Antar Negara Di Indonesia Berdasarkan Hukum Perdata Internasional, Kertha Patrika, Volume 39, Nomor 3, 2017,https://doi.org/10.24843/KP.2017.v39.i03.p03.

Laurensius Arliman S, Partisipasi Masyarakat Di Dalam Pengelolaan Uang Desa PascaUndang-Undang Nomor 6 Tahun 2014 Tentang Desa, Jurnal Arena Hukum, Volume 12, Nomor 2, 2019, https://doi.org/10.21776/ub.arenahukum.2019.01202.5.

Laurensius Arliman S, Mewujudkan Penegakan Hukum Yang Baik Di Negara Hukum Indonesia, Dialogica Jurnalica, Volume 11, Nomor 1, 2019, https://doi.org/10.28932/di.v11i1.1831.

Laurensius Arliman S, Mediasi Melalui Pendekatan Mufakat Sebagai Lembaga Alternatif Penyelesaian Sengketa Untuk Mendukung Pembangunan Ekonomi Nasional, UIR Law Review, Volume 2, Nomor 2, 2018, https://doi.org/10.25299/uirlrev.2018.vol2(02).1587

Laurensius Arliman S, Peranan Filsafat Hukum Dalam Perlindungan Hak Anak Yang Berkelanjutan Sebagai Bagian Dari Hak Asasi Manusia, Doctrinal, Volume 1, Nomor 2,2016.

Laurensius Arliman S, Ni Putu Eka Dewi, Protection of Children and Women's Rights in Indonesia through International Regulation Ratification, Journal of Innovation, Creativity and Change Volume 15, Nomor 6, 2021.

Laurensius Arliman S, Gagalnya Perlindungan Anak Sebagai Salah Satu Bagian Dari Hak Asasi Manusia Oleh Orang Tua Ditinjau Dari Mazhab Utilitarianisme, Jurnal Yuridis, Volume 3, Nomor 2, 2016, http://dx.doi.org/10.35586/.v3i2.180. 
Laurensius Arliman S, Tantangan Pendidikan Kewarganegaraan Pada Revolusi 4.0, Jurnal Ensiklopedia Sosial Review, Volume 2, Nomor 3, 2020. 